\title{
High Productivity Ethanol Fermentation of Glucose \& Xylose Using Membrane Assisted Continuous Cell Recycle
}

\author{
Gautam Degweker $^{1,2}$, Arvind Lali ${ }^{2 *}$ \\ ${ }^{1}$ DBT-ICT Centre for Energy Biosciences, Institute of Chemical Technology, Matunga, Mumbai, India \\ ${ }_{2}^{2}$ Institute of Chemical Technology, Matunga, Mumbai, India \\ E-mail: arvindmlali@gmail.com
}

Received: 8 September 2020; Revised: 9 December 2020; Accepted: 10 December 2020

\begin{abstract}
Rapid and high yield conversion of xylose to ethanol remains a significant bottleneck in the cost-effective production of ethanol using mixed sugars derived from lignocellulosic biomass (LBM). The present study attempts to circumvent this by separate continuous fermentation of glucose and xylose using high cell densities of a Saccharomyces cerevisiae mutant (ICT-1) and a Scheffersomyces stipitis mutant (M1CD), respectively with the help of external microfiltration membrane assisted cell recycle. Different cell densities and aeration rates for xylose fermentation were studied for optimizing continuous fermentation. Consistent high ethanol yields and productivities of $0.46 \mathrm{~g} / \mathrm{g}$ and 5.19 $\mathrm{g} / \mathrm{L} / \mathrm{h}$ with glucose; and $0.38 \mathrm{~g} / \mathrm{g}$ and $1.62 \mathrm{~g} / \mathrm{L} / \mathrm{h}$ with xylose; were achieved in simple media. This provided an average ethanol yield of $0.44 \mathrm{~g} / \mathrm{g}$ on combined sugars, and average productivity of $3.4 \mathrm{~g} / \mathrm{L} / \mathrm{h}$ which is higher than typical molasses-based batch ethanol fermentation. The study thus highlights the potential of high cell density recycle strategy as an effective approach for separate ethanol fermentation of LBM derived sugars.
\end{abstract}

Keywords: ethanol fermentation, cell recycle, high productivity, biofuels, Saccharomyces cerevisiae mutant (ICT-1), Scheffersomyces stipitis mutant (M1CD)

\section{Introduction}

Bioethanol is the largest produced biofuel in the world ${ }^{1}$ owing to ethanol blending mandates taken up by many countries to reduce net carbon emissions. ${ }^{2}$ Bioethanol used for gasoline blending today is a first generation biofuel being predominantly produced from sugarcane or corn. ${ }^{3}$ Ramifications of diversion of food crops for fuel production have been much explored and debated; and the consensus leans towards the use of non-food sources in the long run., Lignocellulosic biomass (LBM), abundantly available as agricultural and forest residues, provides a non-food renewable source of sugars that can be utilized for the production of a wide range of biochemicals including bioethanol. ${ }^{6,7}$ Fractionation and separation of fermentable sugar components from any LBM requires multiple steps comprising physical, chemical and enzymatic treatments. ${ }^{8,9}$ Typical glucose content in biomass is between $30-50 \%$ while xylose is between $15-30 \%$; and these two together account for more than $90 \%$ of the total fermentable sugars that can be released from LBM. ${ }^{10,11}$ Consequently, both sugars need to be efficiently converted to products for economic viability. ${ }^{12}$

The two sugars, glucose and xylose, are obtained either as mixed or separate process streams depending on

Copyright $(2021$ Arvind Lali, et al.

DOI: https://doi.org/10.37256/sce.212021634

This is an open-access article distributed under a CC BY license

(Creative Commons Attribution 4.0 International License)

https://creativecommons.org/licenses/by/4.0/ 
the strategy used for biomass pre-treatment. The subsequent fermentation strategy to be deployed is thus decided accordingly. Alternatively, the pre-treatment strategy is designed to suit combined or separate sugars fermentation. The choice often depends upon the microbial strains available for sugar fermentation. Extensive screening for efficient xylose fermenting organisms started about two decades back and has resulted in the identification of several bacterial and fungal candidates that could convert xylose to ethanol. ${ }^{13}$ Most strains, however, show low ethanol yields and/or low productivities on xylose, compared to the established C6 fermentations, and thus were not actively pursued as hosts for biofuel production. This applied especially after the emergence of recombinant DNA technology capable of constructing mixed sugars fermenting strains. ${ }^{14,15}$ Efforts have been made over the last two decades by both industrial and academic laboratories to develop mutant strains that will be able to convert the combined sugars to ethanol effectively. ${ }^{16-18}$ Most of these strains come at a cost and may not be easily available due to their extensive patenting ${ }^{19}$ or prevalence of technology licensing. ${ }^{20}$ In addition, the cost of meeting regulatory compliances when using GMO strains in large scale industrial environments for producing an inexpensive product such as ethanol can be challenging.

Nevertheless, it can be shown that native strains that inherently give good ethanol yields with individual C6 and C5 sugars can indeed be separately deployed at high cell densities to attain industrially relevant combined volumetric productivities. This simple approach if successfully deployed can provide the desired robustness and competitiveness to the overall biomass-based bioethanol production.

Strategies for retention of cells to attain high cell densities and their prolonged use in a sustained manner have been reviewed by Westman et al. ${ }^{21}$ High cell density fermentation with cell recycle has been attempted by many for ethanol from glucose and sucrose. Laplace et al. ${ }^{22}$ used a cell retaining fritted continuous reactor; Ben Chaabane et al. ${ }^{23}$, Lee et al. ${ }^{24}$ and Park et al. ${ }^{25}$ used membranes; Santos et al. ${ }^{26}$ used flocculation; while Pereira et al. ${ }^{27}$ used cell-centrifuge for cell recycle. However, there is no study that mentions high cell density recycle of $S$. stipitis for xylose fermentation except the work reported by Laplace et al. ${ }^{22}$ Laplace et al. used continuous xylose fermentation using S. stipitis in high cell density (HCD) processes using flocculation as a means for cellular retention. They reported an ethanol yield of 0.36 $\mathrm{g} / \mathrm{g}$ on xylose at productivity of $0.60 \mathrm{~g} / \mathrm{L} / \mathrm{h}$. Flocculation of yeast cells is a complex process and cannot be regarded as a reproducible strategy at several thousand litre scale of fermentation. High cell density with cell recycle through tubular or hollow-fibre microfiltration membranes holds greater potential for significantly improving HCD fermentation productivities in a scalable manner.

The present study was therefore undertaken to explore and optimize the use of the external membrane unit assisted cell recycle HCD ethanol fermentation using economically viable media with synthetic glucose and xylose as would be obtained from physio-chemical pre-treatment of LBM. ${ }^{28-30}$

\section{Materials and methods}

\subsection{Materials}

\subsubsection{Chemicals and reagents}

D-Xylose, D-Glucose, malt extract, yeast extract, agar, peptone and potato dextrose agar were procured from HiMedia Laboratories, India. All other chemicals were analytical grade reagents procured from SD Fine Ltd, India.

\subsubsection{Culture and seed cultivation}

The glucose fermenting strain (ICT-1) used in this study was a result of random UV mutagenesis of locally procured Baker's yeast ${ }^{31}$ while the xylose fermenting strain (M1CD) used in the work was obtained through random UV mutagenesis of S. stipitis CBS 5773 mutant. ${ }^{31}$ Both ICT-1 and M1CD are the results of an earlier exhaustive work on screening and mutating a large number of ethanol producing strains on glucose and xylose as individual substrates. ${ }^{31}$ The cultures were maintained on agar slants with the following MGYEP composition: Malt extract $3 \mathrm{~g} / \mathrm{L}$; Glucose $10 \mathrm{~g} / \mathrm{L}$; Yeast extract $3 \mathrm{~g} / \mathrm{L}$; Peptone $5 \mathrm{~g} / \mathrm{L}$; Agar $20 \mathrm{~g} / \mathrm{L} .^{31,32}$ The slants were used to prepare inoculum cultures.

\subsubsection{Growth \& production media}

The ICT-1 strain inoculum was grown on: $\mathrm{MgSO}_{4} \cdot 7 \mathrm{H}_{2} \mathrm{O} 0.5 \mathrm{~g} / \mathrm{L} ; \mathrm{KH}_{2} \mathrm{PO}_{4} 1.5 \mathrm{~g} / \mathrm{L} ;\left(\mathrm{NH}_{4}\right)_{2} \mathrm{SO}_{4} 3.0 \mathrm{~g} / \mathrm{L}$; Yeast 
Extract $2 \mathrm{~g} / \mathrm{L}$; Glucose $50 \mathrm{~g} / \mathrm{L}$ at a pH 5.5. ${ }^{31}$ However, the continuous fermentation was carried out using the production medium: $\mathrm{MgSO}_{4} \cdot 7 \mathrm{H}_{2} \mathrm{O} 0.5 \mathrm{~g} / \mathrm{L} ; \mathrm{KH}_{2} \mathrm{PO}_{4} 1.5 \mathrm{~g} / \mathrm{L} ;\left(\mathrm{NH}_{4}\right)_{2} \mathrm{SO}_{4} 3.0 \mathrm{~g} / \mathrm{L}$; Urea $3.3 \mathrm{~g} / \mathrm{L}$; and Glucose $50 \mathrm{~g} / \mathrm{L}$. The growth medium for M1CD strain inoculum was: $\mathrm{MgSO}_{4} \cdot 7 \mathrm{H}_{2} \mathrm{O} 1.0 \mathrm{~g} / \mathrm{L} ; \mathrm{KH}_{2} \mathrm{PO}_{4} 2.0 \mathrm{~g} / \mathrm{L} ;\left(\mathrm{NH}_{4}\right)_{2} \mathrm{SO}_{4} 3.0 \mathrm{~g} / \mathrm{L}$; Yeast Extract 2 $\mathrm{g} / \mathrm{L}$; and Xylose $50 \mathrm{~g} / \mathrm{L}$, at $\mathrm{pH} 5.5 .{ }^{31}$ Continuous fermentation with M1CD strain was carried out using the production medium: $\mathrm{MgSO}_{4} \cdot 7 \mathrm{H}_{2} \mathrm{O} 1.0 \mathrm{~g} / \mathrm{L} ; \mathrm{KH}_{2} \mathrm{PO}_{4} 2.0 \mathrm{~g} / \mathrm{L} ;\left(\mathrm{NH}_{4}\right)_{2} \mathrm{SO}_{4} 3.0 \mathrm{~g} / \mathrm{L}$; Urea $3.3 \mathrm{~g} / \mathrm{L}$; Xylose $50 \mathrm{~g} / \mathrm{L}$, also at pH 5.5. The growth and production media were autoclaved (OAT-G-52, Osworld Scientific Equipment, India) at $121^{\circ} \mathrm{C}$ for $20 \mathrm{~min}$ (without urea) and cooled to room temperature before use. Stock urea solution was filter sterilized using a $0.2 \mu \mathrm{m}$ sterile filter (Millex Syringe Filters, Merck, Germany) and added into the pre-autoclaved, cooled production medium under aseptic conditions. The inoculum was grown at $28^{\circ} \mathrm{C}, 200 \mathrm{rpm}$ in sterile shake flasks and $5 \mathrm{~L}$ jacketed glass bioreactors (Biostat ${ }^{\circledR}$ B plus, Sartorius, Germany).

\subsubsection{Seed culture}

Isolated yeast colonies of respective yeasts were transferred from MGYEP slants to $100 \mathrm{~mL}$ of growth media containing $50 \mathrm{~g} / \mathrm{L}$ sugars and incubated at $28^{\circ} \mathrm{C}$ and $200 \mathrm{rpm}$ for $24 \mathrm{~h}$. The cell culture was then transferred to increased volumes of growth media every $24 \mathrm{~h}$ to increase the seed volume in the following steps: from $100 \mathrm{~mL}$ to $500 \mathrm{~mL}$ to $3 \mathrm{~L}$, and finally to $5 \mathrm{~L}$ of growth media containing $50 \mathrm{~g} / \mathrm{L}$ sugar (glucose or xylose) every $24 \mathrm{~h}$ under same conditions. The final seed stage was then allowed to grow in a $5 \mathrm{~L}$ UniVessel ${ }^{\circledR}$ jacketed glass fermenter (Biostat ${ }^{\circledR} \mathrm{B}$ plus, Sartorius, Germany) for $36 \mathrm{~h}$ before its aseptic transfer to the production bioreactor ( $2 \mathrm{~L}$ UniVessel ${ }^{\circledR}$, Biostat ${ }^{\circledR}$ B plus, Sartorius, Germany). This seed expansion strategy was developed for rapid seed volume expansion.

\subsection{Methods}

\subsubsection{Estimation of glucose, xylose and ethanol}

Sugar and ethanol containing samples were filtered and analysed on an Agilent 1200 series HPCL system (Agilent Technologies, USA) consisting of a quaternary pump, automatic sample injector, column oven and a refractive index (RI) detector; using an Aminex HPX 87H ion-exclusion column (300 mm $\times 7.8 \mathrm{~mm}$, BioRad, USA) in $5 \mathrm{mM} \mathrm{H}_{2} \mathrm{SO}_{4}$ mobile phase at a flow rate of $0.6 \mathrm{~mL} / \mathrm{min}$ with the column was maintained at $50{ }^{\circ} \mathrm{C} .{ }^{33}$ Data was collected using Agilent ChemStation software (version B.03.01(317), Agilent Technologies, USA). Standard curves for glucose, xylose and ethanol were obtained and used for quantification. All analyses were done in triplicates.

\subsubsection{Determination of wet and dry cell weight}

A $15 \mathrm{~mL}$ sample was drawn from the medium containing growing cells (shake-flasks or bioreactors) and centrifuged at $10000 \mathrm{rpm}$ for $5 \mathrm{~min}$ on a refrigerated centrifuge (Eppendorf centrifuge 5810R, Eppendorf, Germany). The settled cell pellet after decanting the supernatant was weighed and expressed as wet cell weight (WCW) per mL of sample volume. Dry cell weight (DCW) was determined as described by Hatch et al. ${ }^{34}$ using a dry hot air oven (RDHO-50, Remi Laboratory Instruments, India).

\subsubsection{Cell count and viability}

Samples drawn from flasks or bioreactors were analysed as described by Gilliland et al. ${ }^{35}$ for cell count and viability. The suspension was loaded onto an improved Neubauer's chamber and immediately observed under the light microscope (BX51, Olympus, Japan) at 400× magnification. The unstained yeast cells were considered as viable cells and the total viability was determined in terms of viable cells $/ \mathrm{mL}$ of broth. Viable cell count was also determined by the plate count method using Potato Dextrose Agar. ${ }^{36}$

\subsubsection{Batch fermentation}

Individual strains were transferred from MGYEP slants into the growth medium containing $50 \mathrm{~g} / \mathrm{L}$ sugar and grown at $28^{\circ} \mathrm{C}$ and $200 \mathrm{rpm}$ agitation for $24 \mathrm{~h}$. These cultures were used as inocula for batch fermentation. $10 \% \mathrm{w} / \mathrm{v}$ of wet cell weight from these inocula was used for seeding production medium containing $50 \mathrm{~g} / \mathrm{L}$ sugar. Batch studies were carried 
out in a $2 \mathrm{~L}$ jacketed glass fermenter with an exhaust condenser (Biostat ${ }^{\circledR}$ B plus, Sartorius, Germany) at $28^{\circ} \mathrm{C}$ and 200 rpm and $\mathrm{pH} 5.5$ as described by Das. ${ }^{31}$ All batch fermentations were carried out in triplicates.

\subsubsection{Inoculum for cell recycle}

The seed culture from the $5 \mathrm{~L}$ seed bioreactor was transferred aseptically into the production bioreactor. The working volume of the production bioreactor was maintained at $1 \mathrm{~L}$ by recycling the culture through a microfiltration membrane assembly (CFP-2-E-4X2MA, $850 \mathrm{~cm}^{2}, 1 \mathrm{~mm}$ lumen inner diameter, GE Healthcare, UK) and permeating out excess liquid while retaining cells within the bioreactor. This method was used to increase the cell concentration in the fermenter. Multiple seed cultures of similar age were pooled into the production bioreactor to attain the desired final cell concentrations in $1 \mathrm{~L}$ working volume before beginning steady-state studies.

\subsubsection{Cell recycle fermenter and microfiltration assembly setup}

The production bioreactor was the $2 \mathrm{~L}$ jacketed glass fermenter with an exhaust condenser (Biostat ${ }^{\circledR} \mathrm{B}$ plus, Sartorius, Germany) operating with $1 \mathrm{~L}$ working volume. A $0.2 \mu$ pore size polysulfone hollow-fibre microfiltration membrane module (CFP-2-E-4X2MA, $850 \mathrm{~cm}^{2}$, lumen inner diameter $1 \mathrm{~mm}$, GE Healthcare, UK) was used to retain and recycle cells back to the bioreactor (Figure 1). The membrane assembly was sterilized by autoclaving at $121^{\circ} \mathrm{C}$ for $20 \mathrm{~min}$ before aseptically connecting with the pre-autoclaved bioreactor. The culture was cycled through the membrane assembly using an appropriate peristaltic pump at a fixed flow rate of $50 \mathrm{ml} / \mathrm{min}$ (Model 520S, Watson-Marlow, UK).

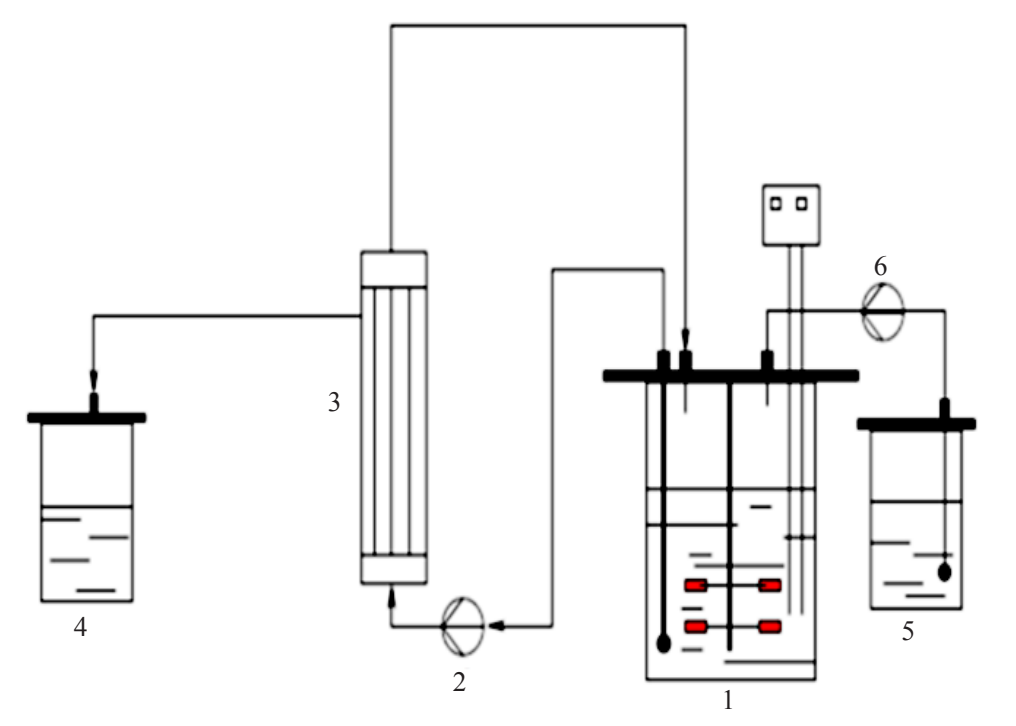

1: Production bioreactor; 2: Peristaltic pump feeding the membrane; 3: Microfiltration membrane;

4: Spent medium containing product; 5: Feed reservoir; 6: Peristaltic pump feeding fresh feed to bioreactor

Figure 1. Schematic representation of a membrane assisted cell recycle bioreactor assembly

The cell-free clear permeate from the system contained ethanol and any un-utilized sugar in the spent media. The retentate containing the cells and bulk of the recirculating medium was directed back into the fermenter. Fresh feed was added continuously into the reactor at the same rate as the rate of permeate collection so that a steady state with constant bioreactor volume could be established.

\subsubsection{Continuous fermentation}

The continuous flow cell recycle bioreactor system was operated at different fixed flow rates in the range 1.5-3.4 $\mathrm{mL} / \mathrm{min}$ that provided average retention times in the range of $4.8-10 \mathrm{~h}$, and dilution rates in the range of $0.1-0.20 / \mathrm{h}$ 
for glucose; and in the range 1-2.4 $\mathrm{mL} / \mathrm{min}$ providing average retention times in the range of $7-15 \mathrm{~h}$ and dilution rates in the range of $0.06-0.14 / \mathrm{h}$ for xylose. The common fermentation conditions were $200 \mathrm{rpm}, 28^{\circ} \mathrm{C}, \mathrm{pH} 5.5$ maintained with $5 \mathrm{~N} \mathrm{NaOH}$; and feed sugar concentration of $50 \mathrm{~g} / \mathrm{L}$ for both sugars. Air was sparged in through a $0.5 \mathrm{~mm}$ ringsparger between 0-1.5 vvm during aeration optimization study as well as during continuous xylose fermentation. Steady state with respect to the continuous fermentation batches was considered established when the outlet sugar and ethanol concentrations became constant with time. The continuous fermentation batches for testing aeration rates were typically run for at least $150 \mathrm{~h}$. Samples were collected at regular intervals. Volumetric bioreactor productivity was optimized by testing substrate consumption at different dilution rates, aeration rates and cell concentrations. Each continuous fermentation run was carried out three times, and the data is reported here as the mean of the three runs.

Statistical analysis of results was done on Microsoft Excel (Microsoft Corporation, USA). Only steady state data was considered for the analysis. Analysis included t-tests for mean differences and one-way analysis of variance. Probabilities under 0.05 were considered significant.

\section{Results and discussion}

\subsection{Batch fermentation}

Batch runs with $10 \%$ inoculum of ICT-1 using $50 \mathrm{~g} / \mathrm{L}$ glucose in production medium in the $2 \mathrm{~L}$ bioreactor showed $95 \%$ sugar consumption in $11 \mathrm{~h}$ and consistently gave an ethanol yield of $0.45 \pm 0.01 \mathrm{~g} / \mathrm{g}$ at productivity of $2.2 \pm 0.2 \mathrm{~g} /$ $\mathrm{L} / \mathrm{h}$. These results are similar to those obtained in typical industrial ethanol fermentations, ${ }^{37}$ although typical molasses or grain-based distillery industry uses sugar concentration in excess of $150 \mathrm{~g} / \mathrm{L}$.

A consistent ethanol yield of $0.38 \pm 0.01 \mathrm{~g} / \mathrm{g}$ using M1CD with $50 \mathrm{~g} / \mathrm{L}$ xylose was achieved consistently with a productivity of $1.05 \pm 0.2 \mathrm{~g} / \mathrm{L} / \mathrm{h}$. M1CD was seen to consume more than $90 \%$ of the xylose in $18 \mathrm{~h}$. du Preez et al. reported a maximum productivity of about $0.90 \mathrm{~g} / \mathrm{L} / \mathrm{h}$ with a yield in the range of $0.43-0.45 \mathrm{~g} / \mathrm{g}$ on $50 \mathrm{~g} / \mathrm{L}$ xylose in batch fermentation using P. stipitis CSIR-Y644 strain. ${ }^{38}$ Agbogbo et al. reported a similar yield of $0.38 \mathrm{~g} / \mathrm{g}$ but at much lower productivity of about $0.21 \mathrm{~g} / \mathrm{L} / \mathrm{h}$ albeit using a lesser cell concentration of $6.5 \mathrm{~g} / \mathrm{L}$ in batch fermentation. ${ }^{39}$

\subsection{Aeration for M1CD in bioreactors}

Aeration has been described as a critical parameter for xylose fermentation to ethanol using S. stipitis and is linked with maintaining the internal redox balance of yeast cells as well as xylose uptake rates. ${ }^{13,40-43}$ Different aeration rates were studied for the continuous fermentation batches using $150 \mathrm{~g} / \mathrm{L}$ wet cell weight density (Figure 2). The rate of xylose uptake was significantly improved when aeration was increased from $0.25 \mathrm{vvm}$ to $1 \mathrm{vvm}(\mathrm{P}=0.000)$. Consistent with other reported studies, ${ }^{41,43,44}$ higher aeration rates positively impacted xylose uptake rate. The yield was also significantly improved by increasing aeration from $0.25 \mathrm{vvm}$ to $1 \mathrm{vvm}(\mathrm{P}=0.013)$.

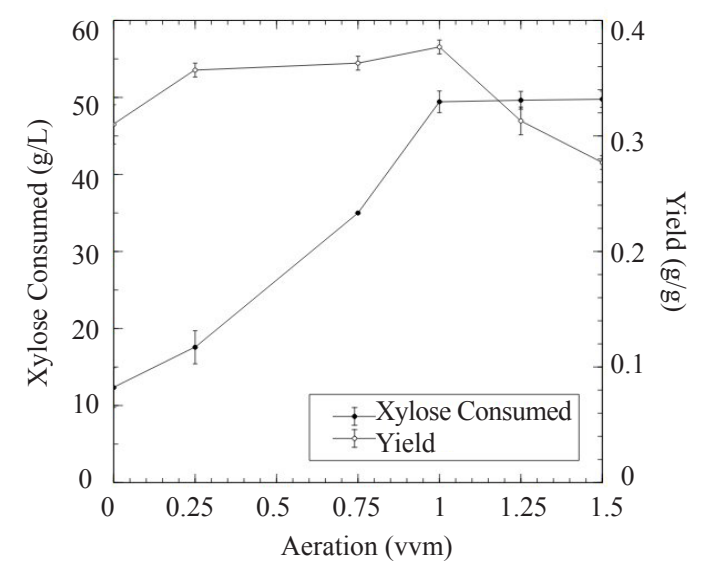

Figure 2. Effect of aeration on xylose fermentation using cell recycle 
But beyond $1 \mathrm{vvm}$, an inverse correlation between aeration and yield was observed as was also reported by Grootjen et al. ${ }^{45}$ An aeration rate of $1 \mathrm{vvm}$ aeration was found to be optimal and gave ethanol yields up to $0.38 \mathrm{~g} / \mathrm{g}$ on xylose for this cell concentration. Such aeration rates result in larger evaporative loss of ethanol and therefore recovery of ethanol from exhaust gases is essential as is the common practice in industrial distilleries wherein outgoing gases (mainly carbon dioxide) is stripped of ethanol. ${ }^{46}$

\subsection{Effect of dilution rates and concentration of cell biomass during cell recycle}

Continuous fermentation was studied at 100 and $150 \mathrm{~g} / \mathrm{L}$ wet weight cell density for glucose as well as xylose (Figure 3); in order to determine optimal hydraulic residence time (HRT) for near complete sugar utilization. At each cell concentration tested, productivity plateaued beyond optimal dilution rates with unutilized xylose detected in the permeate (Figure 3) due to incomplete consumption.

Continuous fermentation batches at optimal dilution rates were operated for up to 15 days at different cell concentrations for ICT-1 (Figures 4) and M1CD (Figure 5). After attaining desired wet cell weight concentration in the production bioreactor, steady state was typically achieved within $30 \mathrm{~h}$ and $15 \mathrm{~h}$ on average for $100 \mathrm{~g} / \mathrm{L}$ and $150 \mathrm{~g} / \mathrm{L}$ cell densities of ICT-1 respectively. The increase in productivity was found to be statistically significant as cell density (DCW) was increased from $26 \mathrm{~g} / \mathrm{L}$ to $39 \mathrm{~g} / \mathrm{L}(\mathrm{P}=0.000)$ while the yield remained the same. Maximum ethanol productivity of $5.19 \mathrm{~g} / \mathrm{L} / \mathrm{h}$ and yield of $0.46 \mathrm{~g} / \mathrm{g}$ was achieved with a cell density (DCW) of $31 \mathrm{~g} / \mathrm{L}$ on glucose (Table 1).
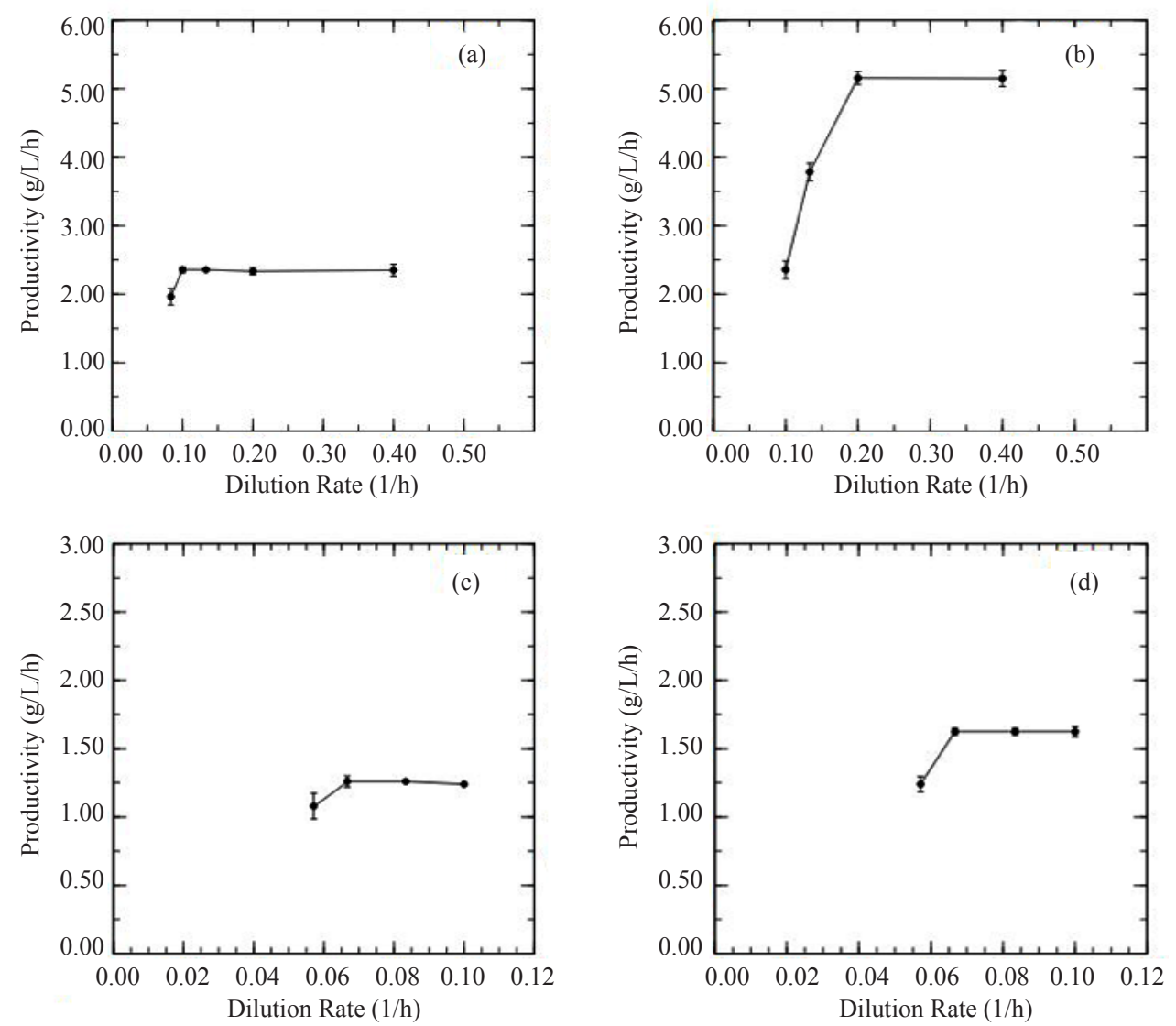

Figure 3. Effect of dilution rate: On glucose fermentation productivity with: (a) $100 \mathrm{~g} / \mathrm{L}$ (WCW); and (b) $150 \mathrm{~g} / \mathrm{L}$ (WCW) of ICT-1; and Xylose fermentation productivity with: (c) $100 \mathrm{~g} / \mathrm{L}$ (WCW); and (d) $150 \mathrm{~g} / \mathrm{L}$ (WCW) of M1CD 
Table 1. Average performance in steady state of three runs using ICT-1 with inlet glucose concentration of $50 \mathrm{~g} / \mathrm{L}$ at dilution rates required to achieve residual outlet sugar concentration at or below $0.10 \mathrm{~g} / \mathrm{L}$

\begin{tabular}{ccccccc}
\hline $\begin{array}{c}\text { Wet Cell Density } \\
(\mathrm{g} / \mathrm{L})\end{array}$ & $\begin{array}{c}\text { Dry Cell Density } \\
(\mathrm{g} / \mathrm{L})\end{array}$ & $\begin{array}{c}\text { Average HRT } \\
(\mathrm{h})\end{array}$ & $\begin{array}{c}\text { Average Residual Glucose } \\
(\mathrm{g} / \mathrm{L})\end{array}$ & $\begin{array}{c}\text { Average Ethanol } \\
(\mathrm{g} / \mathrm{L})\end{array}$ & $\begin{array}{c}\text { Average Yield } \\
(\mathrm{g} / \mathrm{g})\end{array}$ & $\begin{array}{c}\text { Average Productivity } \\
(\mathrm{g} / \mathrm{L} / \mathrm{h})\end{array}$ \\
\hline 100 & 26 & 9.70 & $0.10 \pm 0.01$ & $22.70 \pm 0.03$ & $0.46 \pm 0.01$ & $2.34 \pm 0.03$ \\
150 & 39 & 4.37 & $0.10 \pm 0.01$ & $22.70 \pm 0.03$ & $0.46 \pm 0.01$ & $5.19 \pm 0.03$ \\
\hline
\end{tabular}

Table 2. Average performance in steady state of three runs using M1CD with inlet xylose concentration of $50 \mathrm{~g} / \mathrm{L}$ at dilution rates required to achieve residual outlet sugar concentration at or below $0.30 \mathrm{~g} / \mathrm{L}$

\begin{tabular}{ccccccc}
\hline $\begin{array}{c}\text { Wet Cell Density } \\
(\mathrm{g} / \mathrm{L})\end{array}$ & $\begin{array}{c}\text { Dry Cell Density } \\
(\mathrm{g} / \mathrm{L})\end{array}$ & $\begin{array}{c}\text { Average HRT } \\
(\mathrm{h})\end{array}$ & $\begin{array}{c}\text { Average Residual Glucose } \\
(\mathrm{g} / \mathrm{L})\end{array}$ & $\begin{array}{c}\text { Average Ethanol } \\
(\mathrm{g} / \mathrm{L})\end{array}$ & $\begin{array}{c}\text { Average Yield } \\
(\mathrm{g} / \mathrm{g})\end{array}$ & $\begin{array}{c}\text { Average Productivity } \\
(\mathrm{g} / \mathrm{L} / \mathrm{h})\end{array}$ \\
\hline 100 & 26 & 15 & $0.25 \pm 0.11$ & $18.03 \pm 0.47$ & $0.36 \pm 0.01$ & $1.23 \pm 0.03$ \\
120 & 31 & 13 & $0.23 \pm 0.04$ & $18.25 \pm 0.48$ & $0.37 \pm 0.01$ & $1.44 \pm 0.04$ \\
150 & 39 & 12 & $0.15 \pm 0.03$ & $18.83 \pm 0.31$ & $0.38 \pm 0.02$ & $1.62 \pm 0.03$ \\
\hline
\end{tabular}

For M1CD, the steady state was achieved within $52 \mathrm{~h}, 50 \mathrm{~h}$, and $48 \mathrm{~h}$ on average for 100,120 and $150 \mathrm{~g} / \mathrm{L}$ cell densities, respectively. The increase in productivity and yield was found to be statistically significant as cell density (DCW) was increased from $26 \mathrm{~g} / \mathrm{L}$ to $31 \mathrm{~g} / \mathrm{L}$ to $39 \mathrm{~g} / \mathrm{L}, \mathrm{F}(2,39)=884.25, \mathrm{P}=0.000$ using one-way analysis of variance. Maximum ethanol productivity of $1.62 \mathrm{~g} / \mathrm{L} / \mathrm{h}$ and yield of $0.38 \mathrm{~g} / \mathrm{g}$ was achieved with a cell density (DCW) of $39 \mathrm{~g} / \mathrm{L}$ on xylose (Table 2). These results compare favourably with xylose to ethanol studies using recombinant strains in complex media.

Work reported by Lee et al..$^{24}$ used $140 \mathrm{~g} / \mathrm{L}$ glucose feed to achieve staggering productivity of $85 \mathrm{~g} / \mathrm{L} / \mathrm{h}$ and an ethanol yield of $0.45 \mathrm{~g} / \mathrm{g}$ with $150 \mathrm{~g}$ of dry cell weight $/ \mathrm{L}$ and a dilution rate of $1.31 / \mathrm{h}$. Park et al. ${ }^{25}$ used $100 \mathrm{~g} / \mathrm{L}$ glucose feed to achieve a productivity of $13 \mathrm{~g} / \mathrm{L} / \mathrm{h}$ and a yield of $0.45 \mathrm{~g} / \mathrm{g}$ with a dry cell weight of $58 \mathrm{~g} / \mathrm{L}$, and a dilution rate of $0.3 / \mathrm{h}$. It is normally difficult to understand such a large variation in reported productivities without detailed knowledge of the strains and conditions used.

In comparison, the present study used a maximum dry cell weight of $40 \mathrm{~g} / \mathrm{L}$ of ICT-1 corresponding to $150 \mathrm{~g} / \mathrm{L}$ WCW. While the present study was restricted to non-stop 15 days with the maintained membrane flux of about $3 \mathrm{~L} /$ $\mathrm{m}^{2} / \mathrm{h}$ without any regeneration or CIP (cleaning-in-place) performed during the length of continuous operation, Park et al. ${ }^{25}$ reported operating their experimental set up for up to 60 days without issues in their filtration flux. However, it is important to consider the media composition used in these reported works. Both Lee et al. ${ }^{24}$ and Park et al. ${ }^{25}$ used $8.5 \mathrm{~g} / \mathrm{L}$ yeast extract in media which is an economically unviable option for the production of an inexpensive product like ethanol even if yeast extract were to be locally produced. In another related study, Ben Chaabane et al. ${ }^{23}$ reported remarkably high productivity of $41 \mathrm{~g} / \mathrm{L} / \mathrm{h}$ and yields between 0.33 and $0.41 \mathrm{~g} / \mathrm{g}$ with a $50 \mathrm{~g} / \mathrm{L}$ glucose feed using an ultrafiltration membrane when operating at a total dry cell weight of $156 \mathrm{~g} / \mathrm{L}$ in the fermentation phase reactor. While the study uses an economic medium for production, it reports cell viabilities falling to $42 \%$ at steady state with the study duration of $80 \mathrm{~h}$, that is not enough for sustained fermentation. 

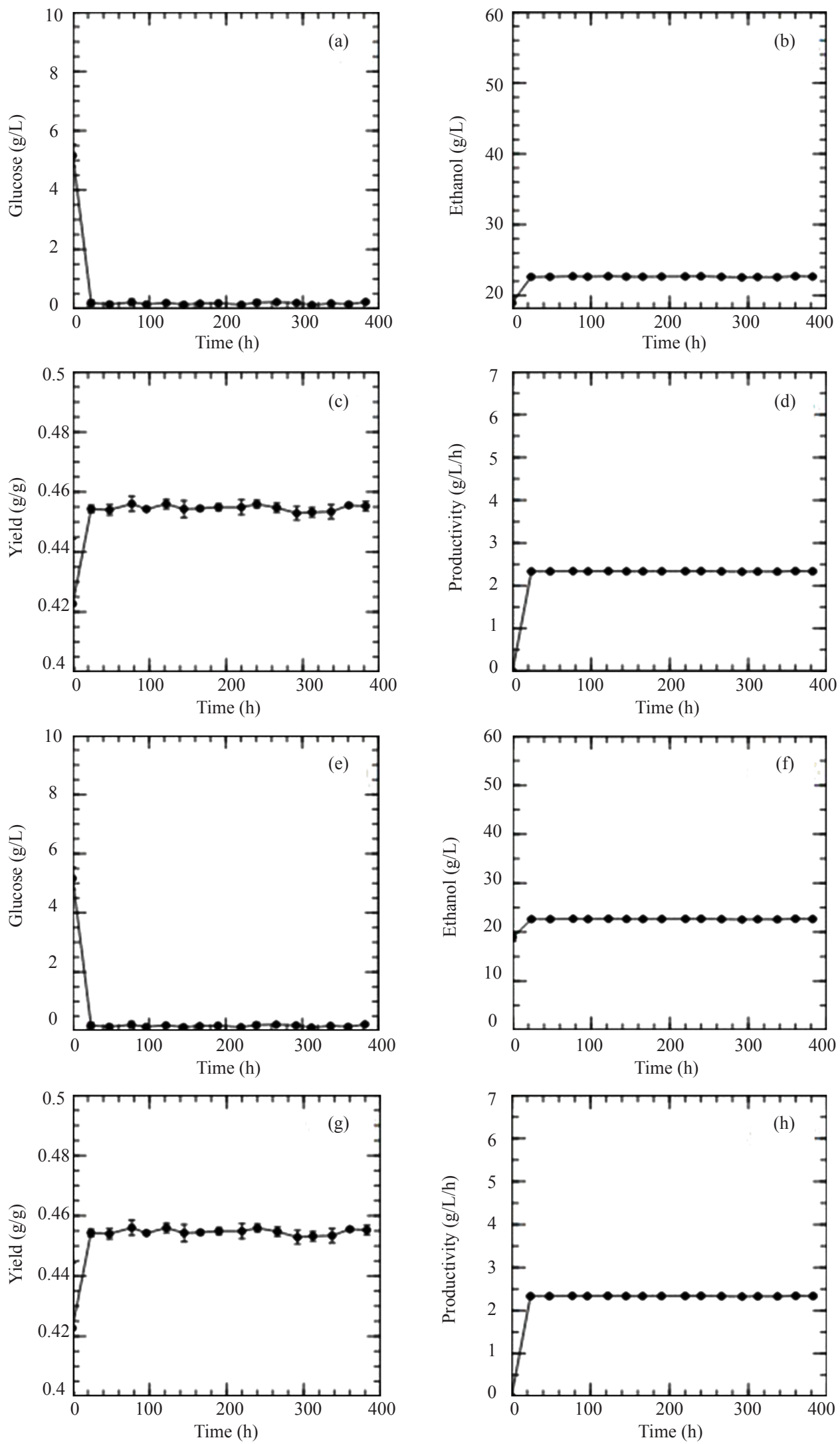

Figure 4. Residual glucose concentration, ethanol concentration, yield and productivity for ethanol fermentation using (a-d) $100 \mathrm{~g} / \mathrm{L}$; (e-h) $150 \mathrm{~g} / \mathrm{L}$ WCW densities of ICT-1 

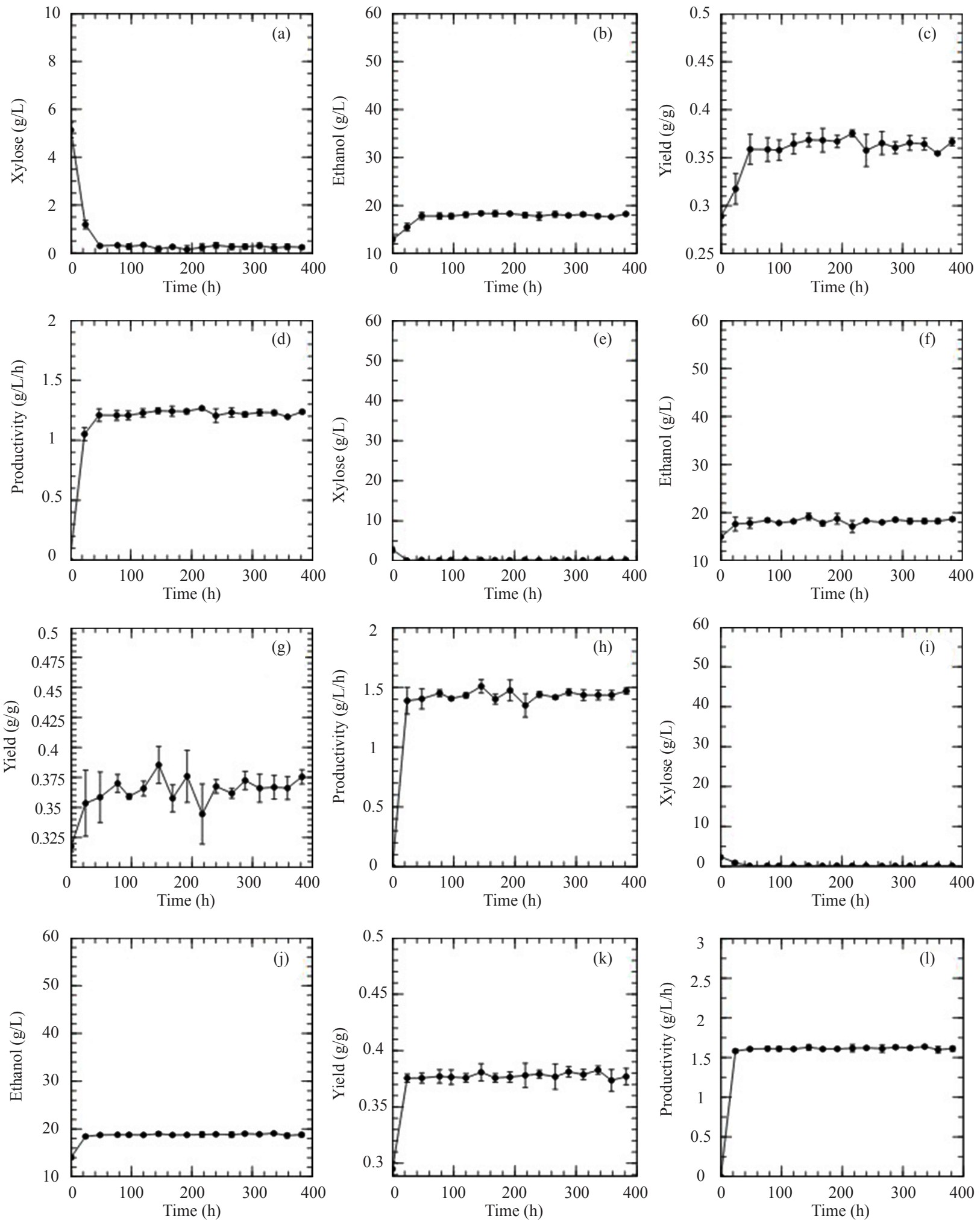

Figure 5. Residual xylose concentration, ethanol concentration, yield and productivity for ethanol fermentation using (a-d) $100 \mathrm{~g} / \mathrm{L}$; (e-h) $120 \mathrm{~g} / \mathrm{L}$; (i-1) $150 \mathrm{~g} / \mathrm{L}$ WCW densities with M1CD

In the case of xylose fermentation, the rate of xylose consumption increased by about $30 \%$ with cell density at $150 \mathrm{~g} / \mathrm{L}$ compared to at $100 \mathrm{~g} / \mathrm{L}$ WCW. These findings are in line with the findings of Agbogbo et al. ${ }^{39}$ The present $^{2}$ 
study achieved maximum productivity of $1.62 \mathrm{~g} / \mathrm{L} / \mathrm{h}$ with a yield of $0.38 \mathrm{~g} / \mathrm{g}$. This performance is better than the only membrane recycled HCD fermentation study reported for xylose fermentation with S. stipitis (NRRL Y7124) ${ }^{22}$ which gave maximum productivity of $0.92 \mathrm{~g} / \mathrm{L} / \mathrm{h}$ with an ethanol yield of $0.33 \mathrm{~g} / \mathrm{g}$.

In a related study using high cell density recycle for xylose fermentation using C. shehatae (ATCC 22984), Sreenath et al ${ }^{47}$ reported maximum productivity of $4.4 \mathrm{~g} / \mathrm{L} / \mathrm{h}$ but used a rich medium with components like yeast extract, amino acid mixture and peptone.

A better understanding of the importance of the present results can be obtained if the glucose and xylose fermentation results are considered in a combined manner and compared to other high cell density recycle studies that have used mixed sugars as substrates. Assuming a typically occurring ratio of 50:20 of glucose to xylose as found in most candidate LBMs, ${ }^{48}$ the present work combined ethanol yield works out to be $0.44 \mathrm{~g} / \mathrm{g}$ on combined sugars at overall average productivity of $3.4 \mathrm{~g} / \mathrm{L} / \mathrm{h}$. Roca et al. ${ }^{49}$ and Ma et al. ${ }^{50}$ reported the use of hollow fibre membranes for continuous cell recycle for mixed ethanol fermentation of mixed sugars. Roca et al. ${ }^{49}$ reported productivity of 5.35 $\mathrm{g} / \mathrm{L} / \mathrm{h}$ using continuous membrane assisted cell recycle for mixed sugar fermentation with a recombinant strain $S$. cerevisiae TMB3001 using expensive and complex media components like vitamins solution and adding ergosterol in the medium. Ma et al. ${ }^{50}$ reported a yield of $0.45 \mathrm{~g} / \mathrm{g}$ at maximum productivity of $2.16 \mathrm{~g} / \mathrm{L} / \mathrm{h}$ using a S. stipitis mutant on mixed sugars while also using an expensive fermentation medium containing $10 \mathrm{~g} / \mathrm{L}$ yeast extract and $20 \mathrm{~g} / \mathrm{L}$ peptone.

Other studies like one by Santos et al. ${ }^{51}$ used a batch cell recycle approach and reported maximum productivity of $2.16 \mathrm{~g} / \mathrm{L} / \mathrm{h}$ with a combined yield of $0.43 \mathrm{~g} / \mathrm{g}$ using $S$. stipitis on mixed sugars with $3 \mathrm{~g} / \mathrm{L}$ yeast extract in the fermentation medium. Sarks et al..$^{33}$ also used a batch cell recycle approach and gave productivities of $1.8 \mathrm{~g} / \mathrm{L} / \mathrm{h}$ with an evolved S. cerevisiae recombinant strain on a biomass hydrolysate containing mixed sugars. It is easy to imagine that composition of the fermentation medium has a significant impact on the final cost of bioethanol. In this regard, most media compositions used by studies cited here use components that are uneconomical for large scale production of bioethanol. In comparison, the present study uses a simple chemically defined inexpensive medium using urea as its nitrogen source instead of costly and complex additives.

\subsection{Cell viability during cell recycle}

The viable cell number at the high cell densities remained similar for both ICT-1 as well as M1CD during the respective 15-day period of operations. Viable cell densities did not deviate from $9 \pm 0.5 \times 10^{8}$ cells $/ \mathrm{mL}$ for $150 \mathrm{~g} / \mathrm{L}$ of ICT-1; and $6 \pm 0.5 \times 10^{8}$ cells $/ \mathrm{mL}$ for $150 \mathrm{~g} / \mathrm{L}$ of M1CD. Viabilities for both cultures remained above $95 \%$ during the periods of continuous fermentation. This suggests that the cell densities were significantly high to inhibit further net growth as noted by Roca et al. ${ }^{49}$ but did not affect the cell viability over time. Some cell aggregation was observed under the microscope at $150 \mathrm{~g} / \mathrm{L}$ cell density for both strains but did not indicate any altered morphology typical of nutrient deficiency as reviewed by Walker et al. ${ }^{52}$ Consistent and maintained yields and productivities observed over 15 days of continuous fermentation suggested that cells were under no significant stress as described by Stanley et al..$^{53}$

\section{Conclusion}

Cost effective production of ethanol using LBM derived sugars places severe cost constraints on both equipment costs and production costs. Correspondingly, therefore, good bioreactor volumetric productivities and good product yields are both important. While C6 conversion to ethanol is industrially established, xylose fermentation has failed to give matching performance. Most attempts have centred on creating recombinant strains that co-utilize C6 and C5 sugars, but have been seen to suffer from high costs of media, regulatory compliances, and lower than desired performances. The current study was successful in showing that the use of separate, continuous high cell density fermentation of glucose and xylose in using defined economical media, and using hollow-fibre microfiltration membrane assisted cell recycle, can be a simpler scalable strategy. The continuous systems designed was operated non-stop for 15 days without loss in cell viability, giving a combined ethanol yield of $0.44 \mathrm{~g} / \mathrm{g}$ on glucose and xylose at a combined volumetric productivity of $3.4 \mathrm{~g} / \mathrm{L} / \mathrm{h}$ using $150 \mathrm{~g} / \mathrm{L} \mathrm{WCW}$ for two indigenous randomly mutated strains. This outcome places the study as an acceptable and economically viable strategy for the production of second-generation ethanol. 


\section{References}

[1] World Bioenergy Association. Global Bioenergy Statistics 2019. 2019.

[2] Ministry of Petroleum and Natural Gas. National Policy on Biofules-2018. 2018.

[3] Wang, M.; Han, J.; Dunn, J. B.; Cai, H.; Elgowainy, A. Efficiency and Sustainability in Biofuel Production: Environmental and Land-Use Research 2015, 7, 249-280.

[4] Tomei, J.; Helliwell, R. Land Use Policy 2016, 56, 320-326.

[5] Poudel, B. N.; Paudel, K. P.; Timilsina, G.; Zilberman, D. Appl. Econ. Perspect. Policy 2012, 34, 637-668.

[6] Carriquiry, M. A.; Du, X.; Timilsina, G. R. Energy Policy 2011, 39, 4222-4234.

[7] Mussatto, S. I.; Dragone, G.; Guimarães, P. M. R.; Silva, J. P. A.; Carneiro, L. M.; Roberto, I. C.; Vicente, A.; Domingues, L.; Teixeira, J. A. Biotechnol. Adv. 2010, 28, 817-830.

[8] Chaturvedi, V.; Verma, P. 3 Biotech, 2013, 3, 415-431.

[9] Vallejos, M. E.; Kruyeniski, J.; Area, M. C. Biofuel Research Journal 2017, 15, 654-667.

[10] Dionisi, D.; Anderson, J. A.; Aulenta, F.; Mccue, A.; Paton, G. J. Chem. Technol. Biotechnol. 2015, 90, 366-383.

[11] Lee, J. J. Biotechnol. 1997, 56, 1-24.

[12] Hemansi; Gupta, R.; Yadav, G.; Kumar, G.; Yadav, A.; Saini, J. K.; Kuhad, R. C. Sustainable Approaches for Biofuels Production Technologies 2019, 7, 121-146.

[13] McMillan, J. D. Xylose Fermentation to Ethanol: A Review. 1993. https://doi.org/10.2172/10117941.

[14] Kobayashi, Y.; Sahara, T.; Ohgiya, S.; Kamagata, Y.; Fujimori, K. E. AMB Express 2018, 8, 1-11.

[15] Chen, Y.; Wu, Y.; Zhu, B.; Zhang, G.; Wei, N. PLoS One 2018, 13, e0199104. https://doi.org/10.1371/journal. pone.0199104.

[16] Kim, S. R.; Ha, S. J.; Wei, N.; Oh, E. J.; Jin, Y. S. Trends in Biotechnology 2012, 274-282.

[17] Harner, N. K.; Wen, X.; Bajwa, P. K.; Austin, G. D.; Ho, C. Y.; Habash, M. B.; Trevors, J. T.; Lee, H. J. Ind. Microbiol. Biotechnol. 2015, 42, 1-20.

[18] Ito, T.; Hotta, A.; Uchida, A.; Tanino, T.; Ogino, C.; Kondo, A.; Ohmura, N. Chemical Engineering Transactions 2010, 20, 103-108.

[19] Mannan, R. Journal of Commercial Biotechnology 2010, 16, 33-46.

[20] Dubiel, J.; Kamensky, C.; Bouwens, T. Clariant and Eta Bio Announce License Agreement on Sunliquid Cellulosic Ethanol Technology in Bulgaria. 2020. https://www.clariant.com/en/Corporate/News/2020/07/Clariant-and-EtaBio-announce-license-agreement-on-sunliquid-cellulosic-ethanol-technology-in-Bulgar (accessed Sep 6, 2020).

[21] Westman, J. O.; Franzén, C. J. Biotechnol. J. 2015, 10, 1185-1195.

[22] Laplace, J. M.; Delgenes, J. P.; Moletta, R.; Navarro, J. M. Process Biochem. 1993, 28, 519-525.

[23] Ben Chaabane, F.; Aldiguier, A. S.; Alfenore, S.; Cameleyre, X.; Blanc, P.; Bideaux, C.; Guillouet, S. E.; Roux, G.; Molina-Jouve, C. Bioprocess Biosyst. Eng. 2006, 29, 49-57.

[24] Lee, C. W.; Chang, H. N. Biotechnol. Bioeng. 1987, 29, 1105-1112.

[25] Park, B. G.; Lee, W. G.; Chang, Y. K.; Chang, H. N. Bioprocess Eng. 1999, 21, 97-100.

[26] Santos, L. D.; Sousa, M. D. B.; Guidini, C. Z.; Resende, M. M. de; Cardoso, V. L.; Ribeiro, E. J.; de Resende, M. M.; Cardoso, V. L.; Ribeiro, E. J. Process Biochem. 2015, 50, 1725-1729.

[27] Pereira, F. B.; Gomes, D. G.; Guimarães, P. M. R.; Teixeira, J. A.; Domingues, L. Biotechnol. Lett. 2012, 34, 45-53.

[28] North, P. H. Method and System for Fractionation of Lignocellulosic Biomass. U.S. Patent 8,657,960 B2. 2014. https://patents.justia.com/patent/9994924.

[29] Lali, A.; Pooja, N.; Varavadekar, J.; Gujarathi, S.; Valte, R.; Birhade, S.; Odaneth, A. Method for Production of Fermentable Sugars from Biomass. U.S. Patent 8,338,139 B2. 2012.

[30] Smit, A.; Huijgen, W. Green Chem. 2017, 19, 5505-5514.

[31] Das, C. Metabolic Analysis of Bioethanol Fermentation. Ph.D, Institute of Chemical Technology, 2012.

[32] Chung, I. S.; Lee, Y. Y. Biotechnol. Bioeng. 1985, 27, 308-315.

[33] Sarks, C.; Jin, M.; Sato, T. K.; Balan, V.; Dale, B. E. Biotechnol. Biofuels 2014, 7, 73.

[34] Hatch, R. T.; Veilleux, B. G. Biotechnol. Bioeng. 1995, 46, 371-374.

[35] Gilliland, R. B. J. Inst. Brew. 1959, 65, 424-429.

[36] Stevenson, K. E.; Richards, L. J. J. Food Sci. 1976, 41, 136-137.

[37] Maiorella, B.; Wilke, C. R.; Blanch, H. W. Adv. Biochem. Eng. 1981, 20, 43-92.

[38] du Preez, J. C.; Bosch, M.; Prior, B. A. Enzyme Microb. Technol. 1986, 8, 360-364.

[39] Agbogbo, F. K.; Coward-Kelly, G.; Torry-Smith, M.; Wenger, K.; Jeffries, T. W. Appl. Biochem. Biotechnol. 2007, $137,653-662$. 
[40] Taniguchi, M.; Itaya, T.; Tohma, T.; Fujii, M. J. Ferment. Bioeng. 1997, 84, 59-64.

[41] Silva, J. P. a; Mussatto, S. I.; Roberto, I. C. Appl. Biochem. Biotechnol. 2010, 162, 1306-1315.

[42] Nigam, J. N. J. Appl. Microbiol. 2001, 90, 208-215.

[43] Jeffries, T. W.; Jin, Y. S. Adv. Appl. Microbiol. 2000, 47, 221-268.

[44] Skoog, K.; Hahn-Hägerdal, B. Appl. Environ. Microbiol., 1990, 56, 3389-3394.

[45] Grootjen, D. R. J.; van der Lans, R. G. J. M.; Luyben, K. C. A. M. Enzyme Microb. Technol. 1990, 12, $20-23$.

[46] de Souza Dias, M. O.; Maciel Filho, R.; Mantelatto, P. E.; Cavalett, O.; Rossell, C. E. V.; Bonomi, A.; Leal, M. R. L. V. Environ. Dev. 2015, 15, 35-51.

[47] Sreenath, H. K.; Jefferies, T. Biotechnol. Lett. 1987, 9, 293-298.

[48] Choudhari, V.; Odaneth, A.; Lali, A. Hydrolytic Potential of Cellulases from Pénicillium Funiculosum and Trichoderma Reesei against PhysicoChemically Different Feedstocks. Adv. Biotechnol. Microbiol. 2017, $5,555665$.

[49] Roca, C.; Olsson, L. Appl. Microbiol. Biotechnol. 2003, 60, 560-563.

[50] Ma, K.; He, M.; You, H.; Pan, L.; Hu, G.; Cui, Y.; Maeda, T. RSC Adv. 2017, 7, 31180-31188.

[51] Santos, S. C.; Dionísio, S. R.; Andrade, A. L. D. De; Roque, L. R.; Costa, A. C. Da; Ienczak, J. L. Int. J. Biol. Biomol. Agric. Food Biotechnol. Eng. 2015, 9, 503-508.

[52] Walker, G. M.; Basso, T. O. Fungal Biol. 2020, 124, 387-397.

[53] Stanley, D.; Bandara, A.; Fraser, S.; Chambers, P. J.; Stanley, G. A. Journal of Applied Microbiology 2010, 109, 1324. 